\title{
SEISMIC SOUNDINGS AT THE MUHOS FORMATION
}

\author{
H. Korhonen and M. T. PorkKa
}

\begin{abstract}
Korhonen H. and Porkka M. T. 1975: Seismic soundings at the Muhos formation. Bull. Geol. Soc. Finland 47, 19-24.
\end{abstract}

\begin{abstract}
The Muhos formation near the city of Oulu in Finland consists of sedimentary rocks lying on the Precambrian bedrock. The thickness of this Jotnian formation varies from a few tenth of meters to one kilometer. The formation is covered by Quaternary deposits. Seismic refraction surveys made at selected sites on the formation show velocities from 300 to $1900 \mathrm{~m} / \mathrm{s}$ for Quaternary deposits and from 4700 to $5800 \mathrm{~m} / \mathrm{s}$ for the basement. In Jotnian sedimentary rocks the velocities vary from 2000 to $4100 \mathrm{~m} / \mathrm{s}$ generally increasing with depth. At site Tupos, in the middle of the formation the refraction profiling, however, did not yield results from depths greater than $200-300 \mathrm{~m}$. This is in disagreement with the well-velocity survey, which indicated higher velocities at greater depths. The contradiction might be explained by a low velocity layer situated near the top of the formation. The density determinations support this interpretation.
\end{abstract}

H. Korbonen and M. T. Porkka, Department of Geopbysics, University of Oulu, SF-90100 Oulu 10, Finland.

\section{Introduction}

After discovering the Muhos sediment formation in 1938 (Brenner 1941) in the association of site investigations for water power station Pyhäkoski at Oulujoki river in Northern Finland, this formation has been a subject of many geophysical and geological studies. It consists of Jotnian sedimentary rocks, which exist as rather rare exceptions on our Precambrian shield (Simonen \& Kouvo 1955, Simonen 1960).

Fig. 1 shows the location of the sediment formation. Its extensions to the sea are almost unknown. The formation is covered by Quaternary deposits such as loose sand and sulfidic silt, whose thickness is from a few meters up to 100 meters. Therefore its boundaries are not very well known. More detailed studies, just in progress, will bring some changes to the map.

The thickness of the Jotnian sedimentary rocks seems to vary considerably. There are only a few deep drillings penetrating the formation. According to these drillings the basement complex was found at Tupos, site 4, at a depth of 977 meters (Kalla 1960) and at Muhos, site 16, at a depth of 524 meters (Simonen \& Kouvo, 1955). At the western side of Hailuoto island the basement complex was reached in two deep drillings at site 11 at a depth of 98 meters and at site 14 at a depth of 155 meters (Veltheim 1969). 


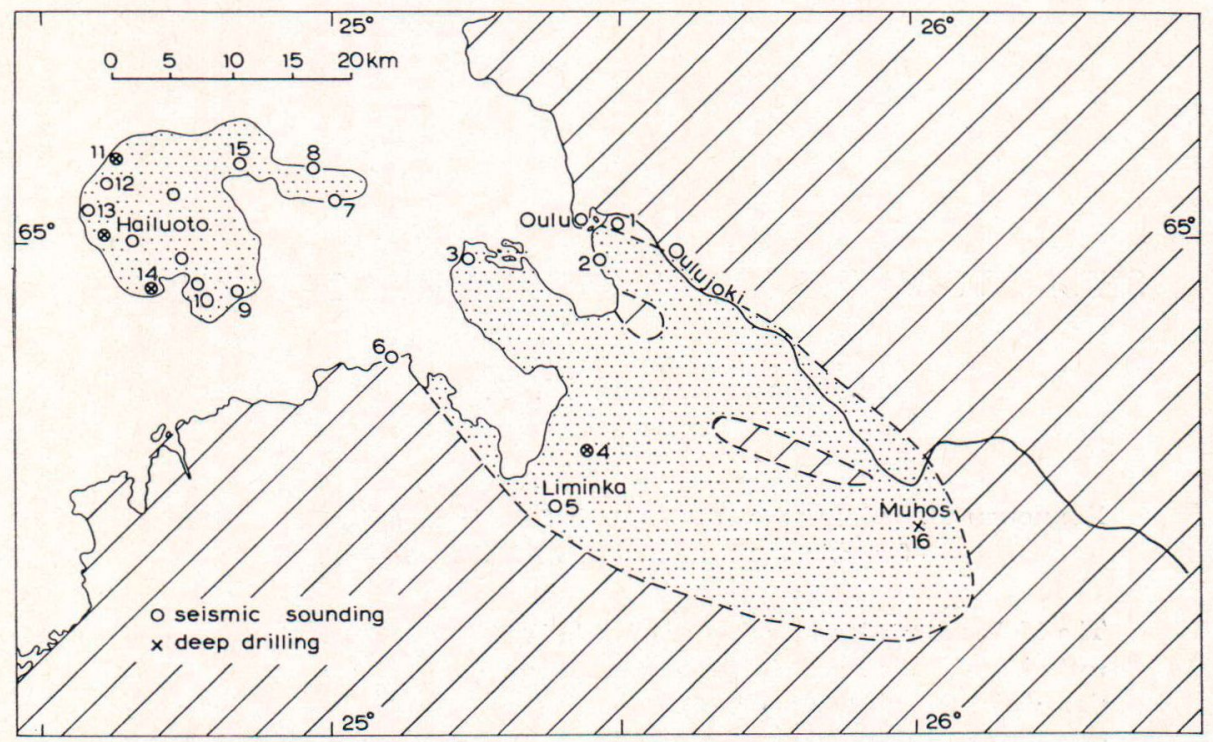

Fig. 1. The location of the Muhos sedimentary formation. The numbers refer to TABLE 1 and to the text.
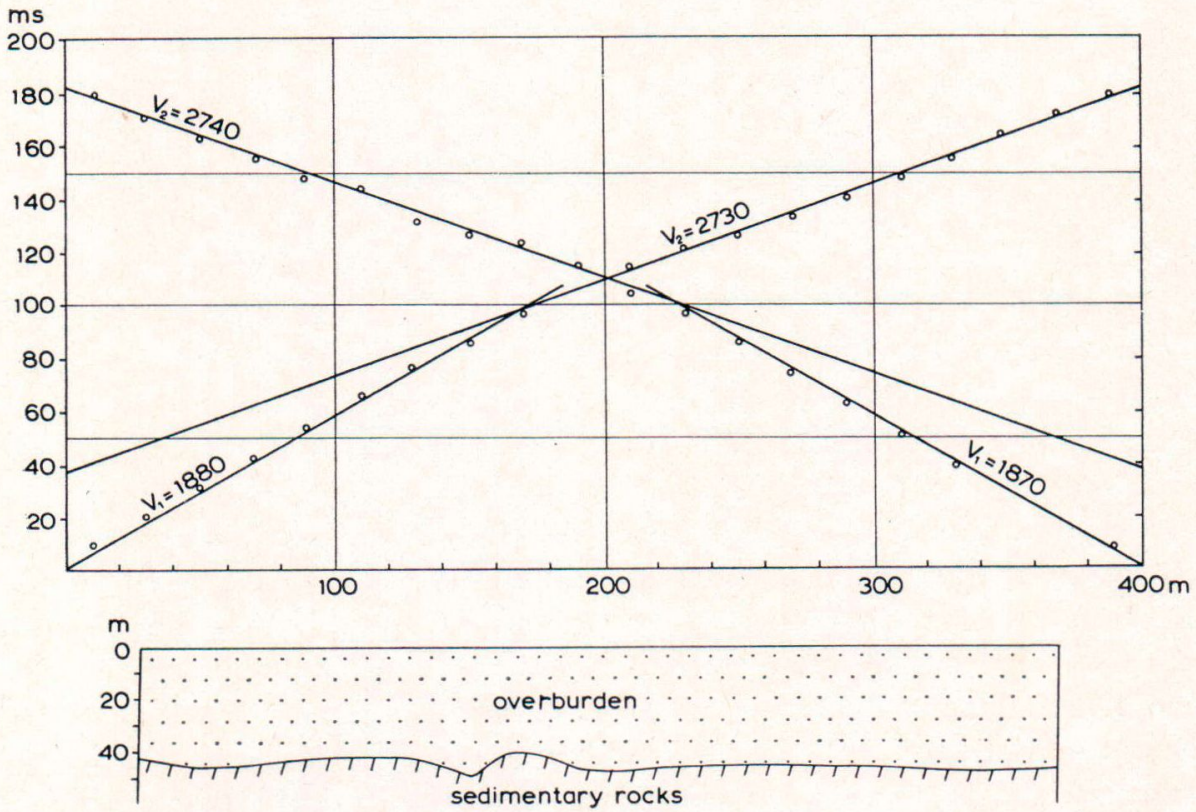

Fig. 2. Travel time curves from refraction lines at site 3 with detailed profiling of the surface of sedimentary rocks. 
According to the results from the Muhos drill hole (Simonen \& Kouvo 1955) the proportion of common types of sedimentary rocks occuring in the formation are red and brown siltstone and shales $81.5 \%$, green shales $11.1 \%$, sandstones and conglomerates $7.4 \%$. Information about the composition and stratigraphy of the formation in Hailuoto island is shown in Fig. 3.

\section{Seismic soundings}

Seismic soundings were made in this area by the Geological Survey of Finland, Geophysical Department, University of Oulu, and different private companies. For overall viewing a collection of refraction seismic results is given in table 1.
All the sites in table 1 lie on the formation except site 1 , which is on the basement complex ca. 2 kilometers from the boundary of the formation. At site 6 in Lumijoki, Varjakka the formation was found somewhat outside the boundaries presented in geological maps. At this site as well as at site 5, Liminka, Kirkonmäki the top of the sediment formation rises near the surface. Figures 2 and 3 show examples of travel time curves. At site 3, in Fig. 2 corresponding velocities from reversed shots are rather similar being for the overburden $1870-1880 \mathrm{~m} / \mathrm{s}$ and for the formation $2730-2740 \mathrm{~m} / \mathrm{s}$. The detailed interpretation of the surface of the formation is also shown in this figure. Seismic velocities in the Quaternary deposits differ significantly from those in the formation allowing seismic determination of the overburden thickness. Velocity

TABle 1

Results from seismic refraction soundings

\begin{tabular}{|c|c|c|c|c|c|c|}
\hline \multirow[t]{2}{*}{ Site } & & \multicolumn{2}{|c|}{ Quaternary deposits } & \multicolumn{2}{|c|}{ Jotnian sedimentary rocks } & \multirow{2}{*}{$\begin{array}{l}\text { Basement } \\
\text { Velocity } \\
\mathrm{m} / \mathrm{s}\end{array}$} \\
\hline & & $\begin{array}{l}\text { Velocity } \\
\mathrm{m} / \mathrm{s}\end{array}$ & $\begin{array}{l}\text { Thickness } \\
\text { m }\end{array}$ & $\begin{array}{l}\text { Velocity } \\
\mathrm{m} / \mathrm{s}\end{array}$ & $\begin{array}{c}\text { Thickness } \\
\mathrm{m}\end{array}$ & \\
\hline 1 & $\begin{array}{l}\text { Oulu, } \\
\text { Kontinkangas. }\end{array}$ & $300-1800$ & 19 & - & - & $4700-5300$ \\
\hline 2 & Oulu, Oritkari .. & $1650-1900$ & $30-50$ & 3080 & - & - \\
\hline 3 & $\begin{array}{l}\text { Oulunsalo, } \\
\quad \text { Riutunkari ... }\end{array}$ & 1880 & $40-50$ & 2800 & - & - \\
\hline 4 & Liminka, Tupos. & $1350-1700$ & $70-100$ & $2900-3300$ & $\left.895^{*}\right)$ & - \\
\hline 5 & $\begin{array}{l}\text { Liminka, } \\
\text { Kirkonmäki ... }\end{array}$ & $500-700$ & $2-3$ & 2200 & - & \\
\hline 6 & $\begin{array}{l}\text { Lumijoki, } \\
\qquad \text { Varjakka ..... }\end{array}$ & $350-500$ & $3-5$ & 2200 & - & - \\
\hline 7,8 & $\begin{array}{l}\text { Hailuoto, } \\
\quad \text { Santonen ..... }\end{array}$ & 1800 & $45-65$ & $2460-3180$ & $450-600$ & 5300 \\
\hline 9,10 & $\begin{array}{l}\text { Hailuoto, } \\
\text { Hanhinen } . . .\end{array}$ & $1600-1700$ & 30 & $2320-2400$ & 30 & 5300 \\
\hline $11,12,13$ & $\begin{array}{l}\text { Hailuoto, } \\
\text { Marjaniemi ... }\end{array}$ & $1650-1710$ & $35-45$ & $2350-3000$ & $90-120$ & $5100-5800$ \\
\hline 14 & Hailuoto, Pöllä.. & 1500 & 40 & 2700 & 100 & 5500 \\
\hline
\end{tabular}

*) According to deep drilling (Kalla 1960). 


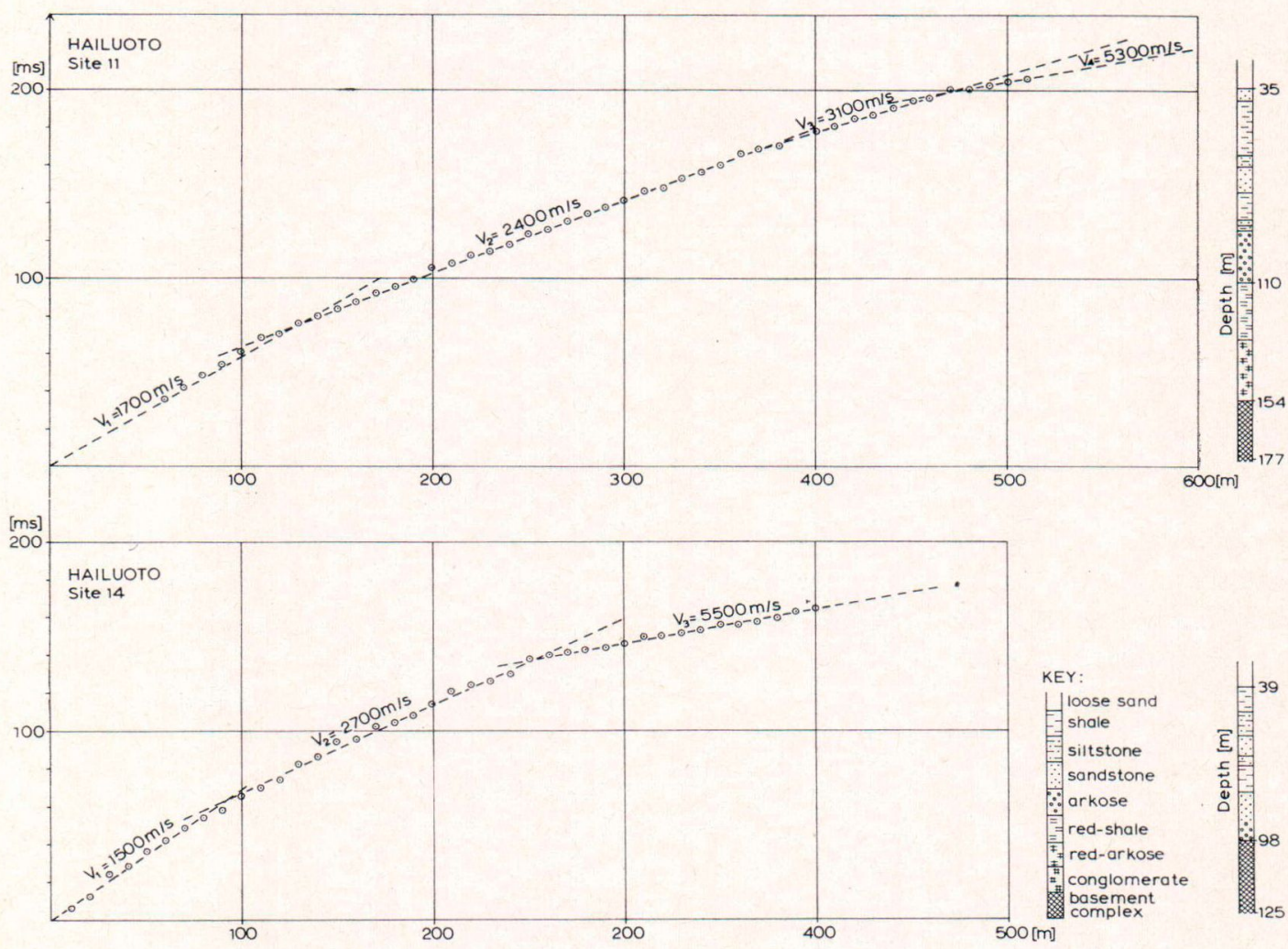

Fig. 3. Travel time curves from refraction profiling at sites 11 and 14 in Hailuoto. The profiles on the right show the stratigraphy of the cores of deep drillings; conglomerate with seismic velocity $4100 \mathrm{~m} / \mathrm{s}$ was found in drilling near site 13 at a depth of $209 \mathrm{~m}$ (Veltheim 1969).

difference between sedimentary rocks and basement complex is also sufficient for seismic methods at least in favourable conditions from which two examples are shown in Fig. 3. At site 11 the velocity seems to increase from $2400 \mathrm{~m} / \mathrm{s}$ to $3100 \mathrm{~m} / \mathrm{s}$ when the core profile shows in the stratigraphy the variation from shale-siltstonesandstone-arkose to red-shale and red-arkose. At site 14 the average velocity for the sedimentary rocks: shale-siltstone-sandstone-arkose is found to be c. $2700 \mathrm{~m} / \mathrm{s}$.

There is, however, an important aspect which should be taken into account in the interpretataion of seismic soundings on this formation. In many sites the velocity increases with depth as demonstrated in Fig. 4. The velocity curves in this figure are nearly parallel, equal velocities being reached at different depths on each site. This might be caused from variations in the thickness of the overburden as well as differences in the properties of the sedimentary rocks in question. The refraction method, however, did not yield any results from the depths below 200-300 m. In the drill hole at Tupos, site 4, a well-shooting was carried out by the Geological Survey of Finland 1963.

An interpretation of the results is shown in Fig. 5 together with density measurements made from the drilling cores (Järvimäki 1973). The density-depth curve shows a maximum at a depth of $200 \mathrm{~m}$ followed by a minimum at a depth of c. $300-400 \mathrm{~m}$. Seismic velocities in the overburden are presented in accordance with refraction results by Korhonen (1961). In the sedimen- 
tary rocks the interval velocities vary considerably. An average increase from $3000 \mathrm{~m} / \mathrm{s}$ to c. $4000 \mathrm{~m} / \mathrm{s}$ is, however, to be found from the top of the formation down to a depth of $850 \mathrm{~m}$. Interval as well as average velocities in Fig. 5 coincide rather well with density curve. The interpretation of well shooting data in the depth interval between $100-300 \mathrm{~m}$ is somewhat ambiguous. The dotted parts in the velocity measurements show a solution supported by the results of refraction soundings and density determination. According to this interpretation a low velocity layer exists at a depth of 200$300 \mathrm{~m}$ in the formation. This low velocity layer might also explain the poor depth penetration observed in the refraction profiling at this site. Further investigations are needed to show the details of the low velocity layer.

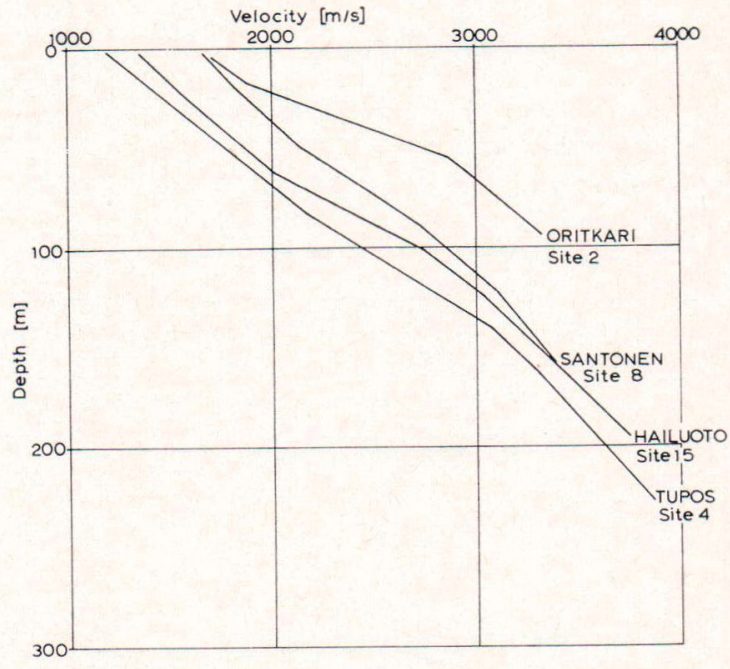

Fig. 4. Variation in velocity-depth curves at different sites.

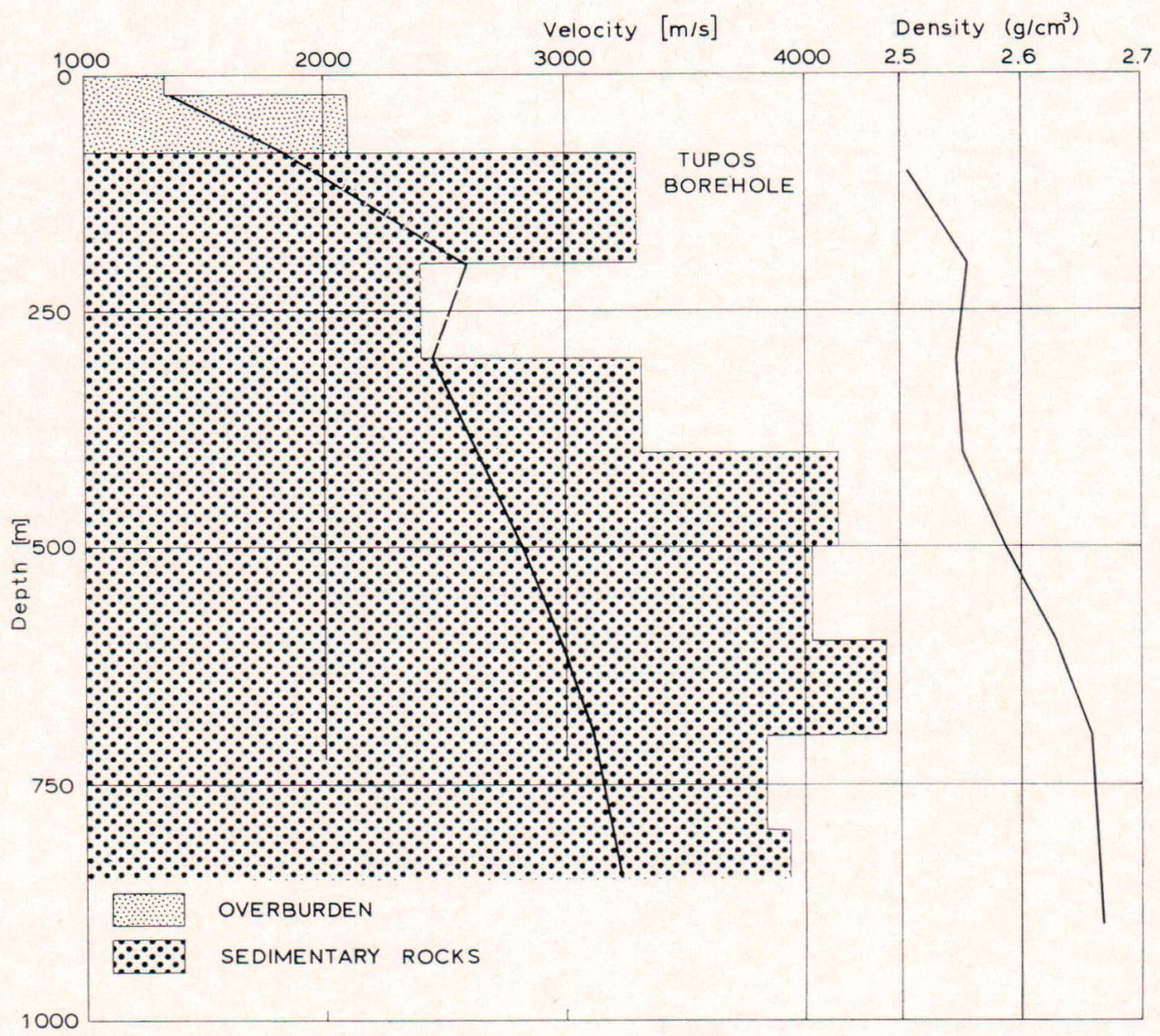

Fig. 5. Well-shooting at Tupos with interval velocities, average velocity and density curves. 


\section{REFERENCES}

Brenner, T. (1941) Ein ungewönliches Kalk-Schlammsteinsediment von Muhos in Mittelfinnland. Geol. Rundschau, 32: 535-549.

Järvimäkr, P. (1973) Tiheysmääritys Tupoksen kairaussydämistä. Geologinen tutkimuslaitos, geofysiikan osasto, työraportti 23. 2. 1973.

Kalla, J. (1960) Muhoksen muodostuman alueella, Limingan Tupoksella suoritettu syväkairaus. Vuoriteollisuus 18: $53-54$.

KORHONEN, H. (1961) Determination of longitudinal wave velocity in siltstone at Tupos. Univ. of Helsinki, Inst. of Seismol. Publ. 49. 10 p.

Simonen, A. and Kouvo, O. (1955) Sandstones in Finland. Bull. Comm. Géol. Finlande, 168: 57-87.

Simonen, A. (1960) Pre-Quaternary rocks in Finland. Bull. Comm. Géol. Finlande, 191: 1- 49.

Veltheim, V. (1969) On the pre-Quaternary geology of the Botnian Bay area in the Baltic Sea. Bull. Comm. Géol. Finlande, 239. 56 p.

Manuscript received, June 30, 1974. 